\title{
Marine microbial biodiversity, bioinformatics and biotechnology (M2B3) data reporting and service standards
}

\author{
Petra ten Hoopen ${ }^{1}$, Stéphane Pesant ${ }^{2}$, Renzo Kottmann ${ }^{3}$, Anna Kopf ${ }^{3,9}$, Mesude Bicak $^{4}$, Simon Claus ${ }^{5}$, \\ Klaas Deneudt ${ }^{5}$, Catherine Borremans ${ }^{6}$, Peter Thijsse ${ }^{7}$, Stefanie Dekeyzer ${ }^{5}$, Dick MA Schaap ${ }^{7}$, Chris Bowler ${ }^{8}$, \\ Frank Oliver Glöckner ${ }^{3,9}$ and Guy Cochrane ${ }^{1 *}$
}

\begin{abstract}
Contextual data collected concurrently with molecular samples are critical to the use of metagenomics in the fields of marine biodiversity, bioinformatics and biotechnology. We present here Marine Microbial Biodiversity, Bioinformatics and Biotechnology (M2B3) standards for "Reporting" and "Serving" data. The M2B3 Reporting Standard (1) describes minimal mandatory and recommended contextual information for a marine microbial sample obtained in the epipelagic zone, (2) includes meaningful information for researchers in the oceanographic, biodiversity and molecular disciplines, and (3) can easily be adopted by any marine laboratory with minimum sampling resources. The M2B3 Service Standard defines a software interface through which these data can be discovered and explored in data repositories. The M2B3 Standards were developed by the European project Micro B3, funded under $7^{\text {th }}$ Framework Programme "Ocean of Tomorrow", and were first used with the Ocean Sampling Day initiative. We believe that these standards have value in broader marine science.
\end{abstract}

Keywords: Data standard, Marine, Molecular, Biodiversity, Microbial, Bioinformatics, Reporting, Interoperability

\section{Background}

An immense wealth of genetic, functional and morphological diversity in marine ecosystems remains unexplored, offering the potential for substantial scientific and biotechnological discoveries. Indeed, significant interest in this area has led to large-scale initiatives, such as Tara Oceans [1], the Global Ocean Survey [2] and Malaspina [3], that target the exploration of marine biodiversity on planetary scales. While the shared goal of such initiatives is the development of an understanding of the composition and ecology of marine microbial ecosystems, each focuses on different parts of the taxonomic breadth of ocean life and only a subset of ocean ecosystems, such as epi- meso- and bathypelagic systems. Ongoing and future marine survey projects will add value to these explorations and will continue to build a powerful marine data infrastructure from which ecosystems biology and

\footnotetext{
* Correspondence: cochrane@ebi.ac.uk

'European Nucleotide Archive, EMBL-EBI, Wellcome Trust Genome Campus Hinxton, Cambridge CB10 1SD, UK

Full list of author information is available at the end of the article
}

biotechnology will derive benefit. Prerequisite for the successful exploitation of acquired data are standards that enable interoperability in the data infrastructure.

Just as marine studies span many disciplines (e.g. biological, oceanographic, molecular), use of data from marine studies requires approaches that traverse the many disciplines, asking questions, for example, of species distribution, physical oceanographic parameters, molecular biology and data licensing. Each discipline has established infrastructure and best practice for the dissemination of its data, including open data repositories, reporting and data standards and discovery and analysis portals. However, there remain major barriers when data are to be used across disciplines that relate to a lack of interoperability between standards and the lack of a consistent environment for the discovery and retrieval of data.

The Marine Microbial Biodiversity, Bioinformatics, Biotechnology Project (Micro B3) [4] unites intensive oceanographic monitoring, thorough biodiversity studies 
Table 1 M2B3 Reporting Standard about an investigation effort

\begin{tabular}{|c|c|c|c|}
\hline Descriptor name & Description of usage & Control vocabulary/format/unit & Example \\
\hline $\begin{array}{l}\text { INVESTIGATION_ } \\
\text { Campaign }\end{array}$ & $\begin{array}{l}\text { Refers to a sampling activity that is } \\
\text { either determined in time, repeated } \\
\text { in time or continuous, e.g. a cruise, } \\
\text { a mesocosm experiment, a time } \\
\text { series, or live data streams }\end{array}$ & Free text & Micro B3-OSD2014 \\
\hline INVESTIGATION_Site & $\begin{array}{l}\text { Refers to the unique identifier and } \\
\text { name of the site/station where the } \\
\text { sampling activity is performed. }\end{array}$ & $\begin{array}{l}\text { Format: < Site ID from OSD Site } \\
\text { Registry }>,<\text { Site name from OSD } \\
\text { Site Registry }>\end{array}$ & $\begin{array}{l}\text { OSD5, Poseidon-E1-M3A } \\
\text { Time Series Station }\end{array}$ \\
\hline $\begin{array}{l}\text { INVESTIGATION } \\
\text { Platform }\end{array}$ & $\begin{array}{l}\text { Refers to the specific unique stage } \\
\text { from which the sampling device was } \\
\text { deployed; includes the platform } \\
\text { category and platform name. }\end{array}$ & $\begin{array}{l}\text { Format: }<\text { Platform category from } \\
\text { SDN:L06 }>,<\text { Platform name }>\end{array}$ & research vessel, FILIA \\
\hline $\begin{array}{l}\text { INVESTIGATION } \\
\text { Authors }\end{array}$ & $\begin{array}{l}\text { List of people who will appear in } \\
\text { the citation of data publications. } \\
\text { Please order the list according to } \\
\text { authorship. The first author is the } \\
\text { contact person. }\end{array}$ & $\begin{array}{l}\text { Format: <LASTNAME }>\text {, < FirstName }>\text {, } \\
<\text { Institution }>\text {, <email }>\end{array}$ & $\begin{array}{l}\text { JONES, Peter, Institute1, } \\
\text { pjones@institute1.eu; } \\
\text { SMITH, Mary, Institute2, } \\
\text { msmith@institute2.eu }\end{array}$ \\
\hline $\begin{array}{l}\text { INVESTIGATION } \\
\text { Project }\end{array}$ & $\begin{array}{l}\text { Refers to the project that organised/ } \\
\text { funded the data/sample collection. }\end{array}$ & Free text & Micro B3 \\
\hline $\begin{array}{l}\text { INVESTIGATION } \\
\text { Objective }\end{array}$ & $\begin{array}{l}\text { Describes the scientific context/ } \\
\text { interest of the sampling activity. } \\
\text { This information is useful to } \\
\text { generate a short abstract as part } \\
\text { of the data set citation. }\end{array}$ & $\begin{array}{l}\text { Free text; } \\
100-500 \text { words }\end{array}$ & A short abstract \\
\hline
\end{tabular}

Mandatory information is in bold and other fields are recommended OSD Sites Registry is a controlled register for OSD sampling Sites (http://mb3is.megx.net/osdregistry). SDN:L06::XX is a controlled terms list describing “CATEGORIES" of platforms (http://seadatanet.maris2.nl/v_bodc_vocab_v2/search.asp?lib=L06).

and high-throughput DNA sequencing of marine genomes, metagenomes and pan-genomes. The project addresses interdisciplinary needs in marine ecosystems biology and biotechnology by considering established best practice within the disciplines and deriving practical least-change means to align practices. Recognising that it is non-trivial to influence deeply-rooted working practices established over decades, we have delivered an extensive programme of workshop-based discussions amongst representatives of the disciplines [22,23].

Table 2 M2B3 Reporting Standard about a sampling event

\begin{tabular}{|c|c|c|c|}
\hline Descriptor name & Description of usage & Control vocabulary/format/unit & Example \\
\hline \multirow[t]{2}{*}{ EVENT_Date/Time } & \multirow{2}{*}{$\begin{array}{l}\text { Date and time when the sampling } \\
\text { event started and ended, e.g. each } \\
\text { CTD cast, net tow, or bucket } \\
\text { collection is a distinct event. }\end{array}$} & Date and time in UTC; & 2013-06-21T14:05:00Z/ \\
\hline & & Format: yyyy-mm-ddThh:mm:ssZ & 2013-06-21T14:46:00Z \\
\hline \multirow[t]{2}{*}{ EVENT_Longitude } & \multirow{2}{*}{$\begin{array}{l}\text { Longitude of the location where } \\
\text { the sampling event started and } \\
\text { ended, e.g. each CTD cast, net } \\
\text { tow, or bucket collection is a } \\
\text { distinct event. }\end{array}$} & Format: \#\#\#.\#\#\#\#\#\# & 035.666666 \\
\hline & & $\begin{array}{l}\text { Decimal degrees; East }=+ \text {, West }=\text {-Format: } \\
\text { Use WGS } 84 \text { for GPS data }\end{array}$ & 035.670200 \\
\hline \multirow[t]{2}{*}{ EVENT_Latitude } & \multirow{2}{*}{$\begin{array}{l}\text { Latitude of the location where the } \\
\text { sampling event started and ended, } \\
\text { e.g. each CTD cast, net tow, or } \\
\text { bucket collection is a distinct event. }\end{array}$} & Format: \#\#.\#\#\#\#\#\# & -24.666666 \\
\hline & & $\begin{array}{l}\text { Decimal degrees; North =+, South =-Format: } \\
\text { Use WGS } 84 \text { for GPS data }\end{array}$ & -24.664300 \\
\hline EVENT_Device & $\begin{array}{l}\text { Refers to the instrument/gear used } \\
\text { to collect the sample or the sensor } \\
\text { used to measure environmental } \\
\text { parameters. }\end{array}$ & Free text & 10L-Niskins or 5L-Bucket \\
\hline EVENT_Method & $\begin{array}{l}\text { Refers to the standard deployment } \\
\text { procedure of the Device. }\end{array}$ & Free text & $\begin{array}{l}12 \text { Niskins were deployed } \\
\text { on a Rosette }\end{array}$ \\
\hline EVENT_Comment & $\begin{array}{l}\text { Report any observation/deviation } \\
\text { from the standard deployment } \\
\text { procedure described in } \\
\text { EVENT_Method }\end{array}$ & Free text & Lots of Jellyfish in the water \\
\hline
\end{tabular}


This effort led to the development of two standards described here. First, the M2B3 Reporting Standard defines and describes fields of information to be made available with marine data sets. Second, the M2B3 Service Standard defines and describes a software interface through which hosts of marine data, such as the public data repositories, can present their marine data holdings.

The resulting standards were used by marine sampling stations and cruises participating in the Micro B3 sampling campaign, Ocean Sampling Day (OSD) [5], a simultaneous world-scale sample and contextual data collection to investigate dynamics and functions of marine microbial diversity. We believe that our work will also be of value to other marine surveys in the future.

\section{M2B3 Reporting Standard}

We have developed the M2B3 Reporting Standard to support data collection and dissemination for those involved in marine microbial sampling. The standard, shown in full in Tables $1,2,3,4,5,6,7$ spans the

Table 3 M2B3 Reporting Standard about a sample

\begin{tabular}{|c|c|c|c|}
\hline Descriptor name & Description of usage & Control vocabulary/format/unit & Example \\
\hline SAMPLE_Title & $\begin{array}{l}\text { A short informative description } \\
\text { of the sample. Must be unique } \\
\text { for each sample, (i.e. for each } \\
\text { filter generated during sampling). }\end{array}$ & 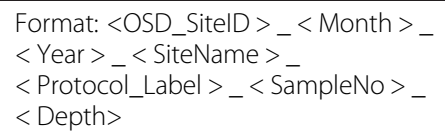 & $\begin{array}{l}\text { OSD3_06_14_Helgoland_ } \\
\text { NPL022_1_surface }\end{array}$ \\
\hline \multirow[t]{3}{*}{ SAMPLE_Depth } & \multirow{3}{*}{$\begin{array}{l}\text { The distance below the surface } \\
\text { of the water at which a } \\
\text { measurement was made or a } \\
\text { sample was collected. }\end{array}$} & Format: \#\#.\#; & \multirow[t]{3}{*}{1.5} \\
\hline & & Positive below the sea surface. & \\
\hline & & SDN:P06:46:ULAA for $m$ & \\
\hline \multirow[t]{2}{*}{ SAMPLE_Protocol_Label } & \multirow{2}{*}{$\begin{array}{l}\text { Identifies the protocol used to } \\
\text { produce the sample, e.g. filtration } \\
\text { and preservation. }\end{array}$} & Term list; & \multirow[t]{2}{*}{ NPL022 } \\
\hline & & $\begin{array}{l}\text { See the SAMPLE_Protocol_Label } \\
\text { in the OSD Protocols Section } \\
\text { for details }\end{array}$ & \\
\hline \multirow[t]{2}{*}{ SAMPLE_Quantity } & \multirow{2}{*}{$\begin{array}{l}\text { Refers to the quantity of } \\
\text { environment that was sampled, } \\
\text { most often with dimensions } \\
\text { Length, Amount, Mass or Time. }\end{array}$} & Format : \#\#\#.\#\#\# & \multirow[t]{2}{*}{20 Litres } \\
\hline & & $\begin{array}{l}\text { See the SAMPLE_Quantity in the OSD } \\
\text { Protocols Section for details }\end{array}$ & \\
\hline \multirow[t]{2}{*}{ SAMPLE_Container } & \multirow{2}{*}{$\begin{array}{l}\text { Refers to the container in which } \\
\text { the sample is stored prior to } \\
\text { analysis. }\end{array}$} & Term list; & \multirow[t]{2}{*}{ Sterivex cartridge } \\
\hline & & $\begin{array}{l}\text { See the SAMPLE_Container in the } \\
\text { OSD Protocols Section for details }\end{array}$ & \\
\hline \multirow[t]{2}{*}{ SAMPLE_Content } & \multirow{2}{*}{$\begin{array}{l}\text { Refers to the content of the } \\
\text { sample container. While the } \\
\text { sample might target a specific } \\
\text { organism (e.g. bacteria), the } \\
\text { sample content might be a } \\
\text { filter or a volume of water. }\end{array}$} & Term list; & \multirow{2}{*}{$\begin{array}{l}\text { Particulate matter on a } \\
0.22 \mu \mathrm{m} \text { pore size filter }\end{array}$} \\
\hline & & $\begin{array}{l}\text { See the SAMPLE_Content in the } \\
\text { OSD Protocols Section for details }\end{array}$ & \\
\hline \multirow{2}{*}{$\begin{array}{l}\text { SAMPLE_Size-Fraction_ } \\
\text { Upper-Threshold }\end{array}$} & \multirow{2}{*}{$\begin{array}{l}\text { Refers to the mesh/pore size } \\
\text { used to pre-filter/pre-sort the } \\
\text { sample. Materials larger than } \\
\text { the size threshold are excluded } \\
\text { from the sample. }\end{array}$} & Term list; & \multirow[t]{2}{*}{ no pre-filtration } \\
\hline & & $\begin{array}{l}\text { See the SAMPLE_Size-Fraction_ } \\
\text { Upper-Threshold in the OSD } \\
\text { Protocols Section for details; } \\
\text { in } \mu \mathrm{m}\end{array}$ & \\
\hline \multirow{2}{*}{$\begin{array}{l}\text { SAMPLE_Size-Fraction_ } \\
\text { Lower-Threshold }\end{array}$} & \multirow{2}{*}{$\begin{array}{l}\text { Refers to the mesh/pore size } \\
\text { used to retain the sample. } \\
\text { Materials smaller than the } \\
\text { size threshold are exclude } \\
\text { from the sample. }\end{array}$} & Term list; & \multirow[t]{2}{*}{0.22} \\
\hline & & $\begin{array}{l}\text { See the SAMPLE_Size-Fraction_ } \\
\text { Lower-Threshold in the OSD } \\
\text { Protocols Section for details; } \\
\text { in } \mu \mathrm{m}\end{array}$ & \\
\hline \multirow{2}{*}{$\begin{array}{l}\text { SAMPLE_Treatment_- } \\
\text { Chemicals }\end{array}$} & \multirow{2}{*}{$\begin{array}{l}\text { Refers to the chemicals } \\
\text { (e.g. preservatives) added } \\
\text { to the sample. }\end{array}$} & Terms list: ChEBl; & \multirow[t]{2}{*}{ None } \\
\hline & & $\begin{array}{l}\text { See the SAMPLE_Treatment_ } \\
\text { Chemicals in the OSD Protocols } \\
\text { Section for details }\end{array}$ & \\
\hline \multirow{2}{*}{$\begin{array}{l}\text { SAMPLE_Treatment_- } \\
\text { Storage }\end{array}$} & \multirow{2}{*}{$\begin{array}{l}\text { Refers to the conditions in } \\
\text { which the sample is stored, } \\
\text { e.g. temperature, light } \\
\text { conditions, time. }\end{array}$} & Term list; & \multirow[t]{2}{*}{-80 degrees Celsius } \\
\hline & & $\begin{array}{l}\text { See the SAMPLE_Treatment_ } \\
\text { Storage in the OSD Protocols } \\
\text { Section for details }\end{array}$ & \\
\hline
\end{tabular}


Table 4 M2B3 Reporting Standard about the sample environmental context

\begin{tabular}{|c|c|c|c|}
\hline Descriptor name & Description of usage & $\begin{array}{l}\text { Control vocabulary/format/ } \\
\text { unit }\end{array}$ & Example \\
\hline ENVIRONMENT_Biome & $\begin{array}{l}\text { Descriptor of the broad ecological context } \\
\text { of a sample. }\end{array}$ & Terms list: EnvO & $\begin{array}{l}\text { ENVO:01000023 for "marine } \\
\text { pelagic biome" }\end{array}$ \\
\hline ENVIRONMENT_Feature & $\begin{array}{l}\text { Compared to biome, feature is a descriptor } \\
\text { of a geographic aspect or a physical entity } \\
\text { that strongly influences the more local } \\
\text { environment of a sample. }\end{array}$ & Terms list: EnvO & $\begin{array}{l}\text { ENVO:00000209 for } \\
\text { "photic zone" }\end{array}$ \\
\hline ENVIRONMENT_Material & $\begin{array}{l}\text { Descriptor of the material that was displaced } \\
\text { by the sampling activity, or material in which } \\
\text { a sample was embedded, prior to the sampling } \\
\text { event. }\end{array}$ & Terms list: EnvO & $\begin{array}{l}\text { ENVO:00002149 for } \\
\text { "sea water" }\end{array}$ \\
\hline \multirow[t]{3}{*}{ ENVIRONMENT_Temperature } & \multirow{3}{*}{$\begin{array}{l}\text { Temperature of water at the time of taking } \\
\text { the sample. Define the parameter according } \\
\text { to Table } 7 .\end{array}$} & Format: \#\#.\# & \multirow[t]{3}{*}{$16.2^{\circ} \mathrm{C}$} \\
\hline & & SDN:P02:75:TEMP & \\
\hline & & SDN:P06:46:UPAA for ${ }^{\circ} \mathrm{C}$ & \\
\hline \multirow[t]{3}{*}{ ENVIRONMENT_Salinity } & \multirow{3}{*}{$\begin{array}{l}\text { Salinity of water at the time of taking the sample. } \\
\text { Define the measurement according to Table } 7 .\end{array}$} & Format: \#\#.\# & \multirow[t]{3}{*}{$39.1 \mathrm{psu}$} \\
\hline & & SDN:P02:75:PSAL & \\
\hline & & SDN:P06:46:UGKG for PSU & \\
\hline ENVIRONMENT_Marine_Region & $\begin{array}{l}\text { It characterises the environment, based on the } \\
\text { latitude and longitude, by reference to geographic, } \\
\text { political, economic or ecological boundaries. }\end{array}$ & Terms list: Marine Regions & $\begin{array}{l}\text { MRGID:21886 for Marine } \\
\text { Ecoregion:South European } \\
\text { Atlantic Shelf }\end{array}$ \\
\hline \multirow[t]{3}{*}{ ENVIRONMENT_Other_Parameters } & $\begin{array}{l}\text { Add as many fields as there are other } \\
\text { environments parameters measured. }\end{array}$ & & \\
\hline & Define the measurement according to Table 7. & & \\
\hline & $\begin{array}{l}\text { See the list of recommended environmental } \\
\text { parameters in Table } 5\end{array}$ & & \\
\hline
\end{tabular}

Mandatory information is in bold and other fields are recommended EnvO is the Environment Ontology (http://www.environmentontology.org/Browse-EnvO). SDN:P02:75:XXXX is a controlled terms list describing "WHAT" is measured (http://seadatanet.maris2.nl/v_bodc_vocab_v2/search.asp?lib=P02). SDN:P06:46:XXXX is a controlled terms list describing "UNITS" of measurements (http://seadatanet.maris2.nl/v_bodc_vocab_v2/search.asp?lib=P06). Marine Regions is a standard list of marine georeferenced place names (http://www.marineregions.org/).

biodiversity, molecular and oceanographic domains and adopts existing standards of each discipline with their mandatory, recommended and optional descriptors (fields of information) (see Figure 1). It represents a unique intersection of existing reporting requirements across all three domains.

We have been strongly guided in this work by the existing standards MEDIN [6], MIxS [7] and Darwin Core [8], the expertise of the Tara Oceans project teams and the International Census of Marine Microbes (ICoMM) project [9], and knowledge of community-established reporting practice into public data archives bestowed by experts from the biodiversity, oceanographic and molecular domain.

The core of the M2B3 Reporting Standard is the M2B3 checklist, (see Figure 2). This core represents the minimal mandatory reporting requirement and consists of descriptors essential to oceanographic, biodiversity and molecular domains, representing research on microbial diversity and function in the marine environment. Marine scientists should be able to report this minimum contextual information about each marine microbial sample irrespective of their scientific expertise and resources available for the sampling.
The M2B3 Reporting Standard includes a set of recommended descriptors (see Figure 2), provision of which brings each marine microbial sample into a rich environmental context and allows better ecological interpretation and experimental reproducibility. The standard's environmental parameters are recommended by the Micro B3 Consortium for description of the environmental landscape of each epipelagic microbial sample (see Figure 3). Here, we have taken an approach including descriptors that draw a balance between analysis requirements-driven methods and current reporting practice in marine microbial sampling. In the requirements-driven approach we analysed several use cases from the area of diatom biology and marine prokaryotic biodiversity. Collated environmental parameters, recorded and reported in these studies in order to answer the scientific questions posed in the studies, represent the optimal list of environmental variables to be measured at the time of microbial sample collection from the epipelagic zone. The current sampling practice-driven approach is the pragmatic counterpart, where environmental variables were identified based on current marine sampling practice surveys and consultations with experts from European marine stations with established long-term sea monitoring programs and a 
Table 5 M2B3 Reporting Standard about environmental measurements

\begin{tabular}{|c|c|c|c|}
\hline Interest & Measurement & Description of usage & Control vocabulary/format/unit \\
\hline \multirow[t]{10}{*}{ General } & \multirow[t]{2}{*}{ Conductivity } & \multirow[t]{2}{*}{ Electrical conductivity of water } & SDN:P02:75:CNDC \\
\hline & & & SDN:P06:46:UECA for $\mathrm{mS} / \mathrm{cm}$ \\
\hline & \multirow[t]{2}{*}{ Temperature } & \multirow[t]{2}{*}{ Temperature of water } & SDN:P02:75:TEMP \\
\hline & & & SDN:P06:46:UPAA for ${ }^{\circ} \mathrm{C}$ \\
\hline & \multirow[t]{2}{*}{ Depth (m) } & \multirow[t]{2}{*}{ Vertical spatial coordinates } & SDN:P02:75:AHGT \\
\hline & & & SDN:P06:46:ULAA for $m$ \\
\hline & \multirow[t]{2}{*}{ Salinity } & \multirow[t]{2}{*}{ Salinity of water } & SDN:P02:75:PSAL \\
\hline & & & SDN:P06:46:UGKG for PSU \\
\hline & \multirow[t]{2}{*}{ Fluorescence } & \multirow{2}{*}{$\begin{array}{l}\text { Raw (volts) or converted } \\
\text { (mg Chla/m^3) fluorescence } \\
\text { of the water }\end{array}$} & SDN:P02:75:FVLT \\
\hline & & & SDN:P06:46:UVLT for volts \\
\hline \multirow{10}{*}{$\begin{array}{l}\text { Nutrient status } \\
\text { of a system }\end{array}$} & \multirow[t]{2}{*}{ Nitrate } & \multirow{2}{*}{$\begin{array}{l}\text { Nitrate concentration parameters } \\
\text { in the water column }\end{array}$} & SDN:P02:75:NTRA \\
\hline & & & SDN:P06:46:UPOX for $\mu \mathrm{mol} / \mathrm{L}$ \\
\hline & \multirow[t]{2}{*}{ Nitrite } & \multirow{2}{*}{$\begin{array}{l}\text { Nitrite concentration parameters } \\
\text { in the water column }\end{array}$} & SDN:P02:75:NTRI \\
\hline & & & SDN:P06:46:UPOX for $\mu \mathrm{mol} / \mathrm{L}$ \\
\hline & \multirow[t]{2}{*}{ Phosphate } & \multirow{2}{*}{$\begin{array}{l}\text { Phosphate concentration } \\
\text { parameters in the water } \\
\text { column }\end{array}$} & SDN:P02:75:PHOS \\
\hline & & & SDN:P06:46:UPOX for $\mu \mathrm{mol} / \mathrm{L}$ \\
\hline & \multirow[t]{2}{*}{ Silicate } & \multirow{2}{*}{$\begin{array}{l}\text { Silicate concentration parameters } \\
\text { in the water column }\end{array}$} & SDN:P02:75:SLCA \\
\hline & & & SDN:P06:46:UPOX for $\mu \mathrm{mol} / \mathrm{L}$ \\
\hline & \multirow[t]{2}{*}{ Ammonium } & \multirow{2}{*}{$\begin{array}{l}\text { Ammonium concentration } \\
\text { parameters in the water } \\
\text { column }\end{array}$} & SDN:P02:75:AMON \\
\hline & & & SDN:P06:46:UPOX for $\mu \mathrm{mol} / \mathrm{L}$ \\
\hline \multirow[t]{3}{*}{$\begin{array}{l}\text { Chemical properties } \\
\text { of a system }\end{array}$} & $\mathrm{pH}$ & $\begin{array}{l}\text { Alkalinity, acidity and pH of the } \\
\text { water column }\end{array}$ & SDN:P02:75:ALKY \\
\hline & \multirow{2}{*}{$\begin{array}{l}\text { Dissolved oxygen } \\
\text { concentration }\end{array}$} & \multirow{2}{*}{$\begin{array}{l}\text { Dissolved oxygen parameters in } \\
\text { the water column }\end{array}$} & SDN:P02:75:DOXY \\
\hline & & & SDN:P06:46:KGUM for $\mu \mathrm{mol} / \mathrm{kg}$ \\
\hline \multirow{4}{*}{$\begin{array}{l}\text { Optical properties } \\
\text { of a system }\end{array}$} & \multirow[t]{2}{*}{ Downward PAR } & Visible waveband radiance and & SDN:P02:75:VSRW \\
\hline & & $\begin{array}{l}\text { Irradiance measurements in the } \\
\text { water column }\end{array}$ & SDN:P06:46:UMES for $\mu \mathrm{E} / \mathrm{m} \wedge 2 / \mathrm{s}$ \\
\hline & Turbidity & Transmittance and attenuance of & SDN:P02:75:ATTN \\
\hline & & & SDN:P06:46:USTU for FTU or NTU \\
\hline Biogeochemistry & Carbon organic & Particulate organic carbon & SDN:P02:75:CORG \\
\hline & particulate (POC) & $\begin{array}{l}\text { concentration in the water } \\
\text { column }\end{array}$ & SDN:P06:46:UGPL for $\mu \mathrm{g} / \mathrm{L}$ \\
\hline & Nitrogen organic & Particulate organic nitrogen & SDN:P02:75:NTOT \\
\hline & ulate (PON) & $\begin{array}{l}\text { concentration in the water } \\
\text { column }\end{array}$ & SDN:P06:46:UGPL for $\mu \mathrm{g} / \mathrm{L}$ \\
\hline & Carbon organic & Dissolved organic carbon & SDN:P02:75:DOCC \\
\hline & dissolved (DOC) & $\begin{array}{l}\text { concentration in the water } \\
\text { column }\end{array}$ & SDN:P06:46:UPOX for $\mu \mathrm{mol} / \mathrm{L}$ \\
\hline & Nitrogen organic & Dissolved organic nitrogen & SDN:P02:75:TDNT \\
\hline & dissolved (DON) & $\begin{array}{l}\text { concentration in the water } \\
\text { column }\end{array}$ & SDN:P06:46:UMGL for mg/L \\
\hline Ecosystem trophic structure & Pigment & Concentration of pigments & SDN:P02:75:CPWC \\
\hline $\begin{array}{l}\& \text { biodiversity (Amount, } \\
\text { Volume or Mass of organisms } \\
\text { in the environment) }\end{array}$ & concentrations & $\begin{array}{l}\text { (e.g. chlorophyll a) extracted } \\
\text { and analysed by fluorometry } \\
\text { or HPLC }\end{array}$ & SDN:P06:46:UMMC for $\mathrm{mg} / \mathrm{m}^{\wedge} 3$ \\
\hline & Picoplankton & Abundance of cells in the & SDN:P02:75:BATX \\
\hline & (Flow Cytometry) & $\begin{array}{l}\text { water column (+other avail. } \\
\text { cell properties) }\end{array}$ & SDN:P06:46:UPMM for \#/m^3 \\
\hline & Nano/Microplankton & & SDN:P02:75:MATX or PATX \\
\hline
\end{tabular}


Table 5 M2B3 Reporting Standard about environmental measurements (Continued)

\begin{tabular}{|c|c|c|c|}
\hline & & $\begin{array}{l}\text { Abundance of cells in the } \\
\text { water column (+other avail. } \\
\text { cell properties) }\end{array}$ & SDN:P06:46:UPMM for \#/m^3 \\
\hline & \multirow[t]{2}{*}{ Meso/Macroplankton } & \multirow{2}{*}{$\begin{array}{l}\text { Abundance of individuals in } \\
\text { the water column (+other } \\
\text { avail. properties) }\end{array}$} & SDN:P02:75:ZATX \\
\hline & & & SDN:P06:46:UPMM for \#/m^3 \\
\hline \multirow[t]{8}{*}{ Ecosystem trophic rates } & \multirow{2}{*}{$\begin{array}{l}\text { Primary Production } \\
\text { (isotope uptake) }\end{array}$} & \multirow{2}{*}{$\begin{array}{l}\text { Primary Production in the } \\
\text { water column }\end{array}$} & SDN:P02:75:PPRD \\
\hline & & & SDN:P06:46:UGDC for $\mathrm{mg} / \mathrm{m} \wedge 3 / \mathrm{d}$ \\
\hline & \multirow{2}{*}{$\begin{array}{l}\text { Primary Production } \\
\text { (oxygen) }\end{array}$} & \multirow{2}{*}{$\begin{array}{l}\text { Primary Production in the water } \\
\text { column }\end{array}$} & SDN:P02:75:PPRD \\
\hline & & & SDN:P06:46:UGDC for $\mathrm{mg} / \mathrm{m}^{\wedge} 3 / \mathrm{d}$ \\
\hline & \multirow{2}{*}{$\begin{array}{l}\text { Bacterial production } \\
\text { (isotope uptake) }\end{array}$} & \multirow{2}{*}{$\begin{array}{l}\text { Bacterial production in the water } \\
\text { column }\end{array}$} & SDN:P02:75:UPTH \\
\hline & & & SDN:P06:46:UGDC for $\mathrm{mg} / \mathrm{m} \wedge 3 / \mathrm{d}$ \\
\hline & \multirow{2}{*}{$\begin{array}{l}\text { Bacterial production } \\
\text { (respiration) }\end{array}$} & \multirow{2}{*}{$\begin{array}{l}\text { Bacterial production in the water } \\
\text { column }\end{array}$} & SDN:P02:75:UPTH \\
\hline & & & SDN:P06:46:UGDC for $\mathrm{mg} / \mathrm{m} \wedge 3 / \mathrm{d}$ \\
\hline
\end{tabular}

Mandatory information is in bold and other fields are recommended.

wealth of expertise, such as Western Channel Observatory in the UK, Station Biologique de Roscoff in France, the Stazione Zoologica in Naples, Italy, or the Biological Institute Helgoland (BAH) of the Alfred Wegener Institute, the Helmholtz Centre for Polar and Marine Research in Germany.

All mandatory and recommended information is described in detail in Tables 1,2,3,4,5,6,7 including specification relating to usage, formal requirements for structure, indication of appropriate units, where applicable, and an example. Descriptors are split for easy navigation into six categories: (1) the marine investigation effort, (2) the sample-taking event, (3) sample-specific details, (4a) the environmental context of the sample, (4b) environmental measurements, (5) marine species found in the sample and (6) description of environmental measurement processes. Descriptors of each conceptual category are prefixed with the category name. Table 4 specifies a broad and local environmental context of a sample including required minimum of measured environmental parameters. Table 5 focuses on specific environmental parameters that complement the fields in Table 4 . Table 7 defines how

Table 6 M2B3 Reporting Standard about organisms in a sample

\begin{tabular}{|c|c|c|c|}
\hline Descriptor name & Description of usage & Control vocabulary/format/unit & Example \\
\hline \multirow[t]{2}{*}{ ORGANISM_Taxon_ID } & \multirow{2}{*}{$\begin{array}{l}\text { An identifier for the nomenclatural } \\
\text { (not taxonomic) details of a } \\
\text { scientific name. }\end{array}$} & Terms list: WoRMS & \multirow{2}{*}{$\begin{array}{l}\text { urn:Isid:marinespecies. } \\
\text { org:taxname: } 345516\end{array}$} \\
\hline & & Format: LSID & \\
\hline \multirow{2}{*}{$\begin{array}{l}\text { ORGANISM_Taxon_- } \\
\text { Scientific_Name }\end{array}$} & \multirow{2}{*}{$\begin{array}{l}\text { The full name of the lowest level } \\
\text { taxon. }\end{array}$} & Terms list: WoRMS & \multirow[t]{2}{*}{ Prochlorococcus marinus } \\
\hline & & Format: Taxon name & \\
\hline ORGANISM_Sex & $\begin{array}{l}\text { The sex of a specimen or collected/ } \\
\text { observed individual(s). }\end{array}$ & $\begin{array}{l}\text { Terms list: } M=\text { Male; } F=\text { Female; } \\
H=\text { Hermaphrodite; I = Indeterminate } \\
\text { (examined but could not be determined; } \\
\text { U = Unkown (not examined); } T=\text { Transitional } \\
\text { (between sexes; useful for sequential } \\
\text { hermaphrodites); } B=\text { Both Male and } \\
\text { Female }\end{array}$ & M \\
\hline ORGANISM_Life_Stage & Indicates the life stage present. & Free text & resting spores \\
\hline \multirow[t]{2}{*}{ ORGANISM_Size } & \multicolumn{3}{|c|}{$\begin{array}{l}\text { Refers to size measurements that are made concurrently to the enumeration and identification of } \\
\text { organisms. }\end{array}$} \\
\hline & \multicolumn{3}{|c|}{ Define the measurement according to Table 7.} \\
\hline \multirow[t]{2}{*}{ ORGANISM_Biovolume } & \multicolumn{3}{|c|}{$\begin{array}{l}\text { Refers to volume measurements/calculations that are made concurrently to the enumeration and } \\
\text { identification of organisms. }\end{array}$} \\
\hline & \multicolumn{3}{|c|}{ Define the measurement according to Table 7.} \\
\hline \multirow[t]{2}{*}{ ORGANISM_Biomass } & \multicolumn{3}{|c|}{$\begin{array}{l}\text { Refers to biomass measurements/calculations that are made concurrently to the enumeration and } \\
\text { identification of organisms. }\end{array}$} \\
\hline & \multicolumn{3}{|c|}{ Define the measurement according to Table 7.} \\
\hline
\end{tabular}


Table 7 M2B3 Reporting Standard about environmental measurement processes

\begin{tabular}{|c|c|c|c|}
\hline Descriptor name & Description of usage & Control vocabulary/format/unit & Example \\
\hline MEASUREMENT_ID & $\begin{array}{l}\text { Unique ID from a controlled } \\
\text { vocabulary. }\end{array}$ & SDN:P02:75:xxxx & $\begin{array}{l}\text { SDN:P02:75:CORG for Particulate } \\
\text { organic carbon concentration } \\
\text { in the water column }\end{array}$ \\
\hline MEASUREMENT_Name & $\begin{array}{l}\text { Common name for the } \\
\text { measurement. }\end{array}$ & Free text & POC \\
\hline MEASUREMENT_Quantity & $\begin{array}{l}\text { Describes the quantity } \\
\text { measured using terms } \\
\text { from the Système } \\
\text { International of units. }\end{array}$ & Free text; SI of units & Mass concentration \\
\hline MEASUREMENT_Dimensions & $\begin{array}{l}\text { Describes the quantity } \\
\text { measured using dimension } \\
\text { terms from the Système } \\
\text { International of units. }\end{array}$ & Free text; SI of units & $M \wedge 1\llcorner\wedge-3$ \\
\hline \multirow[t]{3}{*}{ MEASUREMENT_Currency } & \multirow{3}{*}{$\begin{array}{l}\text { May often refer to a } \\
\text { TAXONOMY_ID or a } \\
\text { CHEMICAL_ID. }\end{array}$} & Free text; & \multirow[t]{3}{*}{ Organic carbon } \\
\hline & & Terms list: WoRMS; & \\
\hline & & Terms list: $\mathrm{ChEBI}$ & \\
\hline MEASUREMENT_Units & $\begin{array}{l}\text { Describes the units of the } \\
\text { quantity measured using } \\
\text { terms from the Système } \\
\text { International of units. }\end{array}$ & SDN:P06:46:xxxx & SDN:P06:46:UGPL for $\mu \mathrm{g} / \mathrm{L}$ \\
\hline MEASUREMENT_Method & $\begin{array}{l}\text { Describes the measurement } \\
\text { method used. Equivalent to } \\
\text { methodological details } \\
\text { provided in a paper. }\end{array}$ & Free text & Mass spectrometry \\
\hline MEASUREMENT_Comment & $\begin{array}{l}\text { Any comment about the } \\
\text { measurement. }\end{array}$ & Free text & $\begin{array}{l}\text { Inorganic carbon removed by } \\
\text { acidification }\end{array}$ \\
\hline
\end{tabular}

Mandatory information is in bold and other fields are recommended.

environmental measurements are captured. The logical relationship between the environmental measurement, measurement description and measurement values is summarised in Figure 4.

\section{M2B3 Reporting standard compliance}

It is worth noting that if all mandatory descriptors from the M2B3 Reporting Standard are reported by a sampling station or a cruise, then a data management centre is frequently able to infer additional descriptors available from the public record. In one example, relating to OSD, the Micro B3 Information System (Micro B3 IS) [10] and the OSD coordinators are able to infer additional descriptors available from public data archives, such as the Data Publisher for Earth and Environmental Science (PANGAEA) for environmental data $[11,12]$ and the European Nucleotide Archive (ENA) for molecular data $[13,14]$. The additional information can be added post hoc for all samples acquired within the OSD campaign since the campaign has standardised and published sampling protocols and a Registry of OSD stations and cruises [15]. The inferred descriptors include, for instance, a sample catalogue number and collection code assigned by the bio-archiving institution where the OSD samples will be centrally deposited. In a second example that applies very broadly across marine samples, remotely sensed data (such as cloud cover, air temperature and wind conditions) can be connected to appropriate records based upon geospatial fields.

Combining information compliant with the M2B3 Reporting Standard from marine sampling laboratories with inferred information has two major advantages: (1) it significantly reduces the reporting burden for the marine sampling laboratories and (2) it ensures that OSD data records created at the molecular data archive will be compliant with the MIxS molecular data standard, Version 4 [16], OSD data records created at the oceanographic data archive will be compliant with the oceanographic Common Data Index (CDI), Version 3 [17] and OSD data records created at the biodiversity data archive will be compliant with the biodiversity OBIS Schema, Version 1.1 [18].

\section{M2B3 service standard}

Six descriptors from the M2B3 Reporting Standard are central to data interoperability across disciplines. These descriptors provide the basis for connecting data points from one discipline to data points in another and are thus the indices upon which data resources providing services must present their data. The interoperability descriptors are: INVESTIGATION_Site, INVESTIGATION_Platform, EVENT_ Date/Time, EVENT_Longitude, EVENT_Latitude and SAMPLE_Depth. 


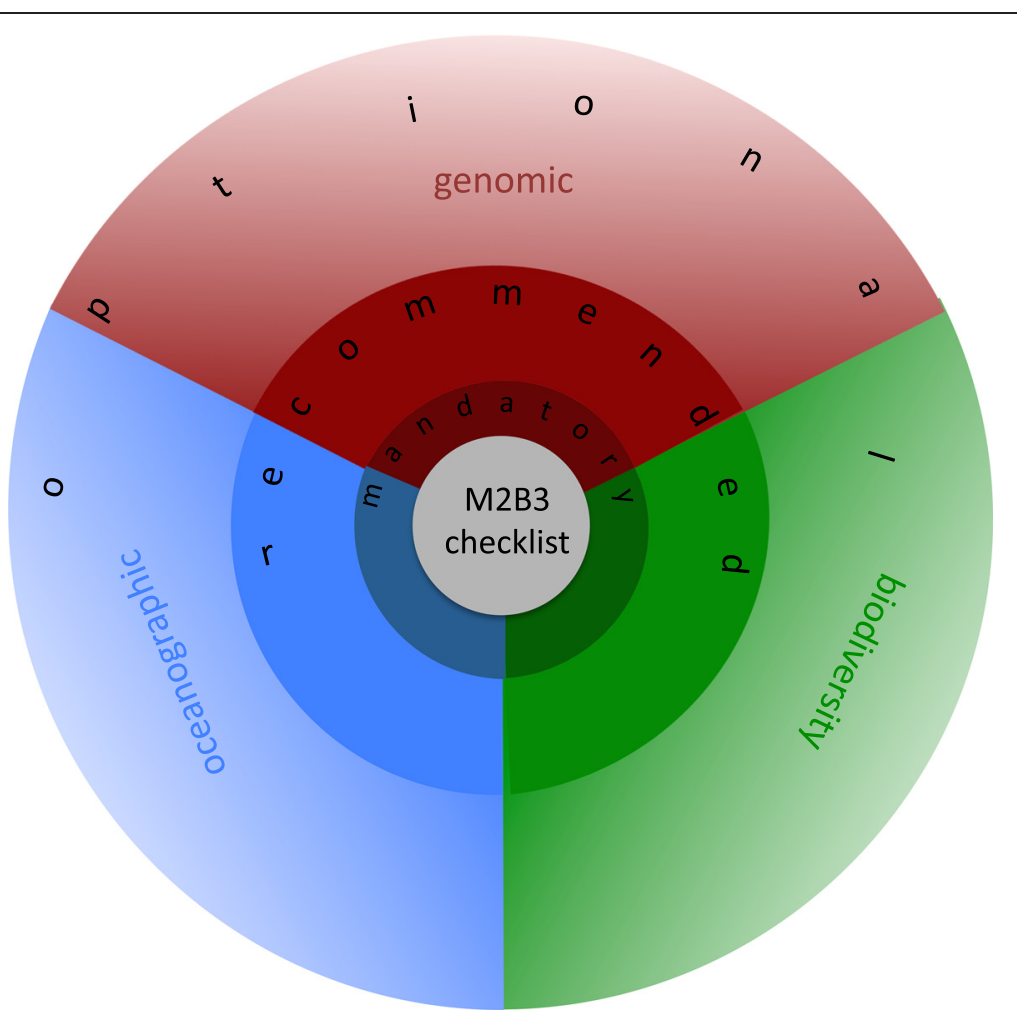

Figure 1 M2B3 Reporting Standard descriptors schematically depicted on the junction of three disciplines, adopting existing standards of each domain.

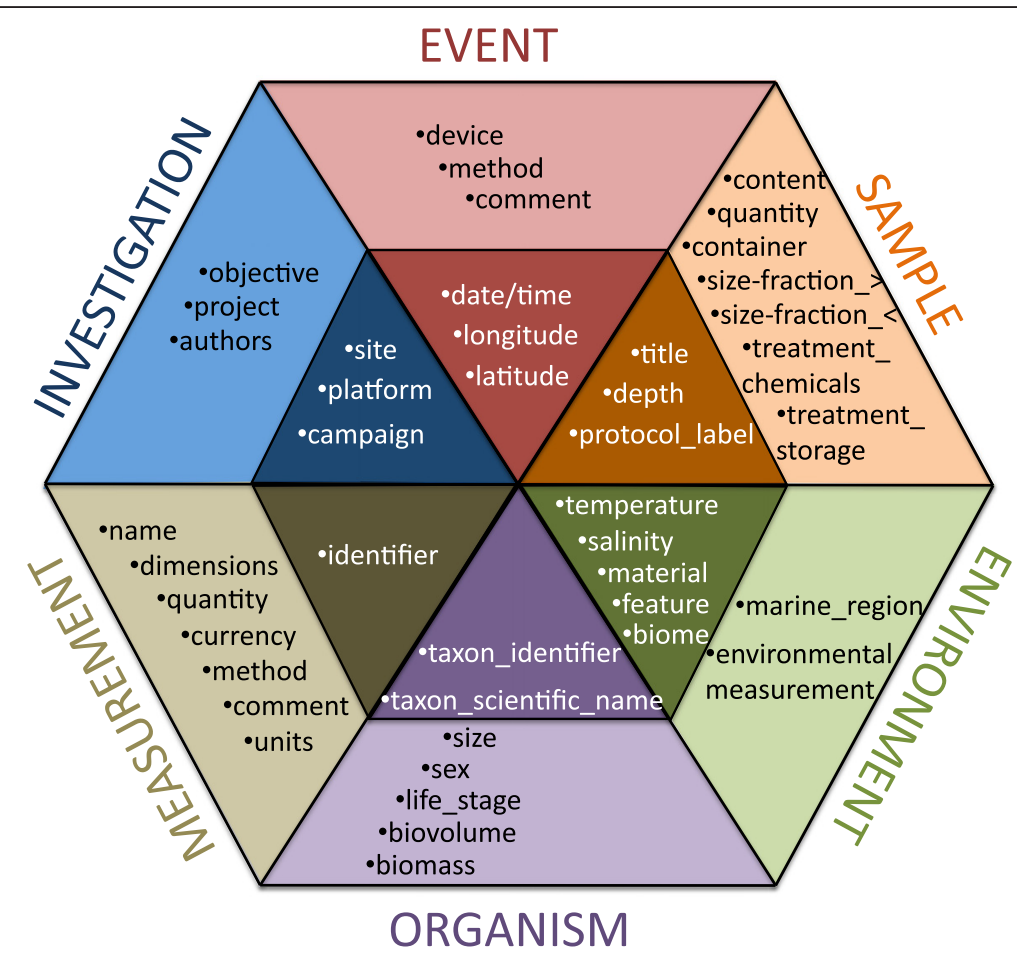

Figure 2 Mandatory and recommended information of the M2B3 Reporting Standard; descriptors are split into six categories represented by coloured triangles, where mandatory descriptors are in the dark-shaded area and recommended information elements are in the light-shaded area. Environmental measurements in the ENVIRONMENT section are further specified in Figure 3. 


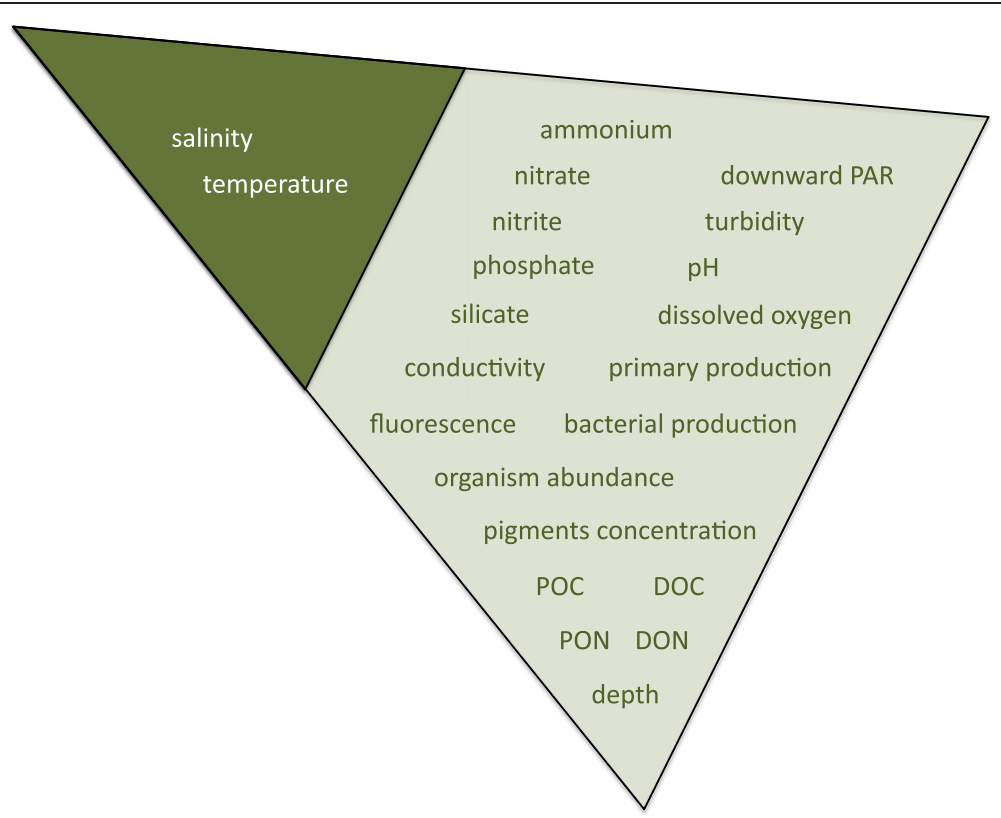

Figure 3 Mandatory (in the dark green area) and recommended (in the light green area) environmental measurements of the M2B3 Reporting Standard.

In order for users of marine data to discover and access data, there is a need for these fields of information to be made searchable in a single and consistent way across relevant data resources.

We define the M2B3 Service Standard as a standardised set of informatics methods through which marine data can be discovered in data resources. The six interoperability descriptors are presented by a compliant data resource using a programmatic service interface that follows Open Geospatial Consortium (OGC) standards, the
Web Map Service (WMS), Web Feature Service (WFS) and/or the OpenSearch protocol. To date, the European Nucleotide Archive, European Ocean Biogeographic Information System (EurOBIS) [19,20], Micro B3 Information System, PANGAEA and SeaDataNet [21] have committed to supporting the M2B3 Service Standard for OSD data.

\section{Conclusions}

The M2B3 Reporting Standard combines reporting requirements of three disciplines. Compliance with the standard

\section{Measurement \\ type \\ Measurement \\ description \\ Measurement \\ values}

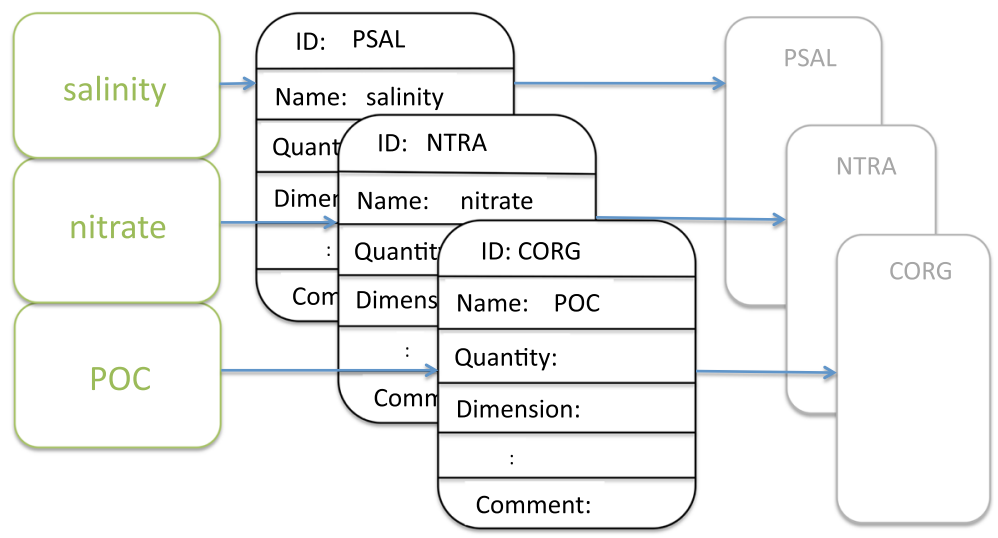

Figure 4 The logical connection between environmental measurements (Table 5), recording of the measurements (Table 7) and measured values, shown on the example of three environmental parameters - salinity, nitrate and carbon organic particulate (POC). 
ensures that the collected data can be correctly directed to and stored in their respective domain-specific data archives, which are the ENA for molecular data and PANGAEA for environmental data and morphology-based biodiversity data. Compliance with the standard allows PANGAEA to create a condensed metadata summary and share it with panEuropean oceanographic and biodiversity information networks, managed by SeaDataNet and EurOBIS, respectively. Micro B3 IS and other data resources compliant with the M2B3 Service standard can discover marine data compliant with the M2B3 Reporting Standard.

During its preparation, development of the M2B3 Reporting Standard and the M2B3 Service Standard allowed experts from the oceanographic, biodiversity and molecular disciplines to review current working practice, to extract and formulate what is essential and universal and to find common ground. Adoption of the M2B3 Reporting Standard will require a similar effort from the marine science community, as already started with the OSD sampling marine laboratories. The ultimate reward will be a unique collection of standardised marine data for the exploration of ecosystem biology and the advance of biotechnology.

\section{Abbreviations \\ CDI: Common Data Index; ENA: European Nucleotide Archive; EurOBIS: European Ocean Biogeographic Information System; ICoMM: International Census of Marine Microbes; M2B3: Marine Microbial Biodiversity, Bioinformatics and Biotechnology; Micro B3: Marine Microbial Biodiversity, Bioinformatics, Biotechnology; Micro B3 IS: Micro B3 Information System; OGC: Open Geospatial Consortium; OSD: Ocean Sampling Day; PANGAEA: Data Publisher for Earth and Environmental Science; SDN: SeaDataNet; WFS: Web Feature Service; WMS: Web Map Service; UTC: Coordinated Universal Time; WGS84: World Geodetic System 1984; GPS: Global Positioning System; LSID: Life Science Identifier.}

\section{Competing interests}

The authors declare that they have no competing interests.

\section{Authors' contributions}

$\mathrm{PH}$ coordinated the M2B3 standards development; SP contributed to the marine aspect of the M2B3 reporting standard, RK, GC, PH, MB and AK contributed to its molecular aspect and SC, KD CB and SD contributed to its biodiversity aspect; G.C DS, PT, RK and SC were leading the work on the M2B3 service standard. CB advised on the use case studies, GC and FOG provided overall guidance. $\mathrm{PH}$ wrote the manuscript with an editorial contribution of SP and GC and a revision by all co-authors. All authors read and approved the final manuscript.

\section{Acknowledgements}

We gratefully acknowledge contribution and comments from participants of the Micro B3 Use Case Workshop [22], Micro B3 Best Practice Workshop [23] and Micro B3 General Assembly.

This project has received funding from the European Union's Seventh Framework Programme for research, technological development and demonstration (Joint Call OCEAN.2011-2: Marine microbial diversity - new insights into marine ecosystems functioning and its biotechnological potential) under grant agreement no 287589

\section{Author details}

${ }^{1}$ European Nucleotide Archive, EMBL-EBI, Wellcome Trust Genome Campus Hinxton, Cambridge CB10 1SD, UK. ${ }^{2}$ PANGAEA - Data Publisher for Earth \& Environmental Science, MARUM Center for Marine Environmental Sciences, Universität Bremen, Hochschulring 18 (Cognium), POP 330 440, 28359
Bremen, Germany. ${ }^{3}$ Max Planck Institute for Marine Microbial Ecology, Microbial Genomics and Bioinformatics Group, Celsiusstr. 1, 28359 Bremen, Germany. ${ }^{4}$ Oxford e-Research Centre (OeRC), University of Oxford, 7Keble Road, Oxford, UK. ${ }^{5}$ Vlaams Instituut voor de Zee, InnovOcean site, Wandelaarkaai 7, B-8400 Oostende, Belgium. ' IFREMER-Centre de BREST, IDM/ SISMER, ZI de la Pointe du Diable, CS 10070, 29280 Plouzane, France. ${ }^{7}$ MARIS BV, Koningin Julianalaan 345 A $2273 \mathrm{JJ}$, Voorburg, The Netherlands. ${ }^{8}$ Environmental and Evolutionary Genomics Section, Institut de Biologie de l'Ecole Normale Supérieure (IBENS), CNRS UMR8197 Inserm U1024, 75005 Paris, France. ${ }^{9}$ Jacobs University Bremen gGmbH, Campusring 1, 28759 Bremen, Germany.

Received: 8 October 2014 Accepted: 17 March 2015

Published online: 08 May 2015

\section{References}

1. Karsenti E, Acinas SG, Bork P, Bowler C, De Vargas C, Raes J, et al. A holistic approach to marine eco-systems biology. PLoS Biol. 2011;9(10):e1001177.

2. Nealson $\mathrm{KH}$, Venter JC. Metagenomics and the global ocean survey: what's in it for us, and why should we care? ISME J. 2007;1:185-7.

3. Malaspina. [http://www.expedicionmalaspina.es/]

4. Micro B3. [http://www.microb3.eu/]

5. OSD. [http://www.oceansamplingday.org]

6. MEDIN. [http://www.oceannet.org/marine_data_standards/]

7. Yilmaz P, Kottmann R, Field D, Knight R, Cole JR, Amaral-Zettler $L$, et al. Minimum information about a marker gene sequence (MIMARKS) and minimum information about any $(\mathrm{x})$ sequence (MIXS) specifications. Nat Biotechnol. 2011;29:415-20.

8. Wieczorek J, Bloom D, Guralnick R, Blum S, Döring M, Giovanni R, et al. An Evolving Community-Developed Biodiversity Data Standard. PLoS One. 2012;7(1):e29715.

9. ICoMM. [http://news.coml.org/descrip/icomm.htm]

10. Micro B3 IS. [http://mb3is.megx.net/]

11. Schindler U, Diepenbroek M. Generic XML-based Framework for Metadata Portals. Comput Geosci. 2008;34(12):1947-55. doi:10.1016/j.cageo.2008.02.023.

12. PANGAEA. [http://www.pangaea.de/]

13. Cochrane G, Alako B, Amid C, Bower L, Cerdeño-Tárraga A, Cleland I, et al. Facing growth in the European Nucleotide Archive. Nucleic Acids Res. 2013;41(D1):D30-5.

14. ENA. [http://www.ebi.ac.uk/ena]

15. OSD Registry. [http://mb3is.megx.net/osd-registry]

16. MlxS, v.4.0. [http://wiki.gensc.org/index.php?title=MlxS]

17. CDI, v.3.0. [http://www.seadatanet.org/Data-Access/Common-Data-Index-CDI]

18. OBIS, v.1.1. [http://www.iobis.org/node/304]

19. Vandepitte L, Hernandez F, Claus S, Vanhoorne B, De Hauwere N, Deneudt K, et al. Analysing the content of the European Ocean Biogeographic Information System (EurOBIS): available data, limitations, prospects and a look at the future. Hydrobiologia. 2011;667(1):1-14.

20. EurOBIS. [http://www.eurobis.org/]

21. SeaDataNet. [http://www.seadatanet.org]

22. Micro B3 Use Case Workshop. [http://www.microb3.eu/sites/default/files/ deliverables/MB3_D4_1_PU.pdf]

23. Micro B3 Best Practice Workshop. [http://www.microb3.eu/sites/default/files/ deliverables/MB3_D4_2_PU.pdf]

\section{Submit your next manuscript to BioMed Central and take full advantage of:}

- Convenient online submission

- Thorough peer review

- No space constraints or color figure charges

- Immediate publication on acceptance

- Inclusion in PubMed, CAS, Scopus and Google Scholar

- Research which is freely available for redistribution 